\title{
IMPROVING THE QUALITY OF LIFE WITH RURAL DEVELOPMENT PROGRAMMES IN GERMANY (2007-2013): EVIDENCE FROM THE EVALUATION
}

Andrea Moser ${ }^{1}$, Heike Peter ${ }^{2}$, Birgit Fengler ${ }^{3}$, Renate Strohm-Lömpcke ${ }^{4}$

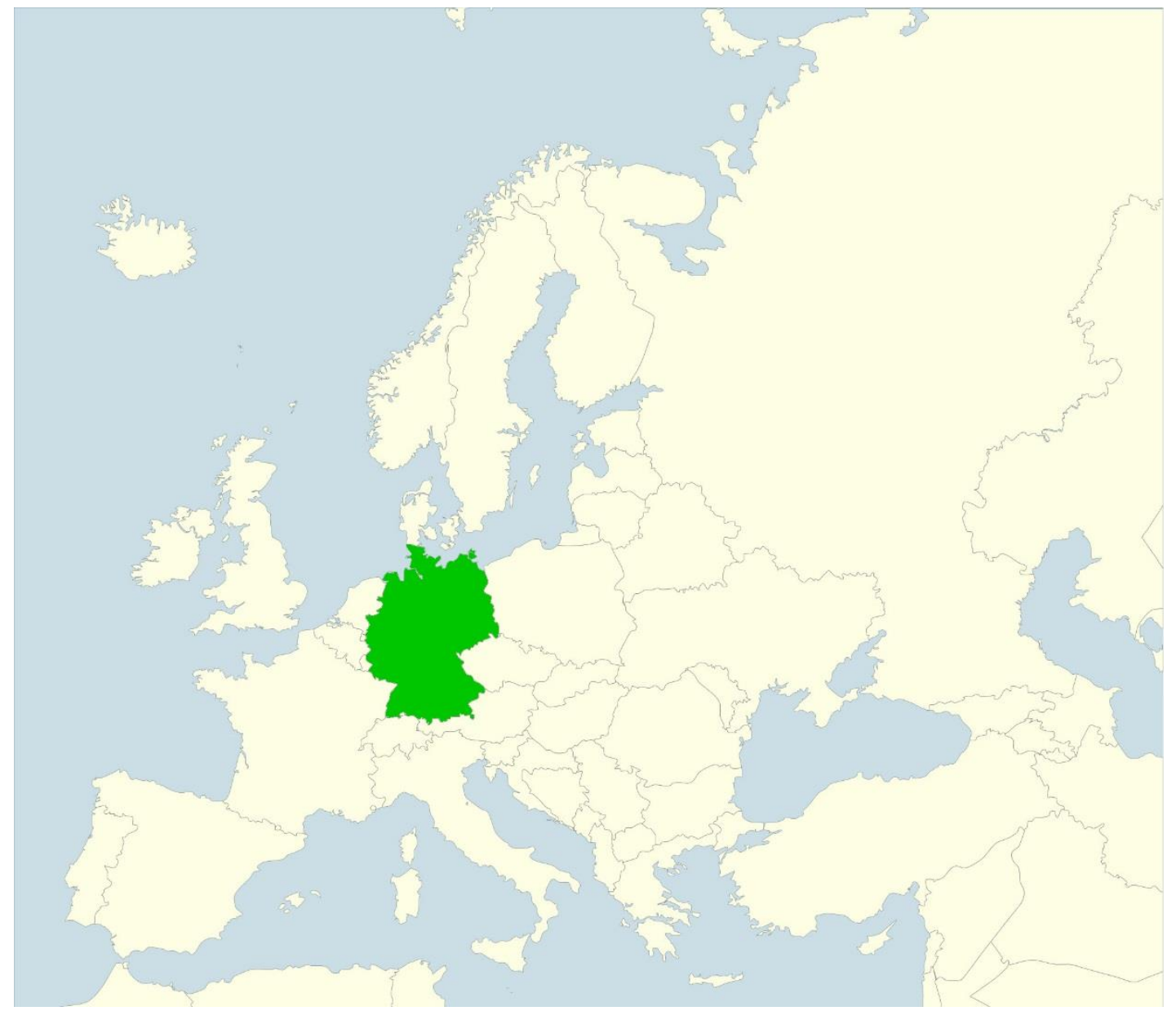

\footnotetext{
1 Andrea Moser, Agrarsoziale Gesellschaft e.V., Kurze Geismarstraße 33, 37073 Göttingen, Germany; e-mail: andrea.moser@asg-goe.de

${ }^{2}$ Heike Peter, Thünen Institute of Rural Studies, Johann Heinrich von Thünen Institute - Federal Research Institute for Rural Areas, Forestry and Fisheries, Bundesallee 64, 38116 Braunschweig, Germany; e-mail: heike.peter@thuenen.de

${ }^{3}$ Birgit Fengler, Thünen Institute of Rural Studies, Johann Heinrich von Thünen Institute - Federal Research Institute for Rural Areas, Forestry and Fisheries, Bundesallee 64, 38116 Braunschweig, Germany; e-mail: birgit.fengler@thuenen.de

4 Dr. Renate Strohm-Lömpcke, RS-LANDKONZEPT, Dorfstraße 25, 17252 Schwarz, Germany, e-mail: info@rslandkonzept.de
} 
Abstract: Improving the quality of life is a strategic priority for the European Union (EU), and is, therefore also a stated goal of development policy for rural areas. The EAFRD Regulation provides the legal framework for this policy. As Germany has a federal structure, the federal states of Germany are responsible for implementing the aims of the rural development programmes (RDPs). As each federal state has taken a different approach to improving the quality of life in rural areas, the effects of these programmes differ. Until now, there was no plan for measuring the success of the RDPs. In this article, we will show how the multidimensional concept of quality of life - which was developed in the 1960s and 1970s and has been applied since then - primarily in the social sciences - was turned into a theory-based research concept for evaluating selected RDPs. The focus of the article is on the theoretical derivation and the development of the research concept; concrete results are presented as examples. Die Ergebnisse zeigen, dass die Verbesserung der Lebensqualität durch die EPLR nur in einzelnen Teilbereichen erreicht wurde. The results show that the improvement in quality of life realized by the EPLR was only achieved in individual areas. Across all of the federal states we observed, the greatest positive effects were found in the dimensions "conditions in residential locations" and "personal activities (leisure etc.)."

Keywords: Quality of life, Rural Development Programmes, Evaluation

Zusammenfassung: Die Verbesserung der Lebensqualität ist eine strategische Priorität der Europäischen Union (EU) und gilt daher auch als erklärtes Ziel der europäischen Entwicklungspolitik für den ländlichen Raum. Die ELER-Verordnung bildet den Rechtsrahmen für diese Politik. Auf Grund des deutschen Föderalismus setzen in Deutschland die Bundesländer diese Ansätze im Rahmen ihrer Entwicklungsprogramme für den ländlichen Raum (EPLR) um. Die Bundesländer haben das Ziel der verbesserten Lebensqualität unterschiedlich ausgestaltet, sodass sich entsprechend die Wirkungen unterscheiden. Zur Messung dieser Wirkungen im Rahmen der Evaluierung der EPLR lag kein Konzept vor. Im vorliegenden Artikel wird dargestellt, wie das multidimensionale Konzept der Lebensqualität, das seit den 1960 er und 1970er Jahren vornehmlich in den Sozialwissenschaften entwickelt und verwendet wird, in ein theoriegeleitetes Untersuchungskonzept der Evaluation ausgewählter EPLR umgesetzt wurde. Dabei stehen die theoretische Herleitung und die Erarbeitung des Untersuchungskonzepts im Vordergrund, konkrete Ergebnisse werden exemplarisch vorgestellt. Die Ergebnisse zeigen, dass die Verbesserung der Lebensqualität durch die EPLR nur in einzelnen Teilbereichen erreicht wurde. Dabei konnten über alle untersuchten Bundesländer hinweg besonders in den Dimensionen „Wohnstandortbedingungen“ und „Persönliche Aktivitäten (Freizeit etc.)“ Wirkungen dargestellt werden.

Schlüsselwörter: Lebensqualität, Entwicklungsprogramme für den ländlichen Raum, Evaluation

\section{Introduction}

The European Agricultural Fund for Rural Development (EAFRD) represents the second pillar of the Common Agricultural Policy (CAP), and thus plays an important role in the development of rural regions of Europe, including those of Germany (Copus et al. 2011).

During the 2007-2013 funding period, improving the quality of life was a stated goal of the rural development policy within the framework of the EAFRD Regulation, and a strategic priority of the European Union (EU). The federal states' Rural Development Programmes (RDP) 2007 to 2013 continued to pursue these objectives. Within the framework of the ex-post evaluation of 
the EAFRD, known as the seven-state evaluation ${ }^{5}$, the effects of these programmes on the quality of life were investigated in greater depth in five federal states. These include Hesse, MecklenburgWestern Pomerania, North Rhine-Westphalia, Lower Saxony, and Schleswig-Holstein (see Forstner et al., 2016; Moser et al., 2016; Peter et al., 2016; Pollermann et al., 2016; Tietz et al., 2016).

Only the revision of the Joint Assessment Framework by the European Rural Development Evaluation Network (EEN, 2014) provided an evaluation question to assess the impact on quality of life at the programme level. Indicators were, however, not identified. Some methodological advice was provided by a working paper (Grieve \& Weinspach, 2010).

In the EPLRs examined, the objective "quality of life" was not defined. Descriptions including housing conditions, good living conditions, attractiveness of rural areas, future viability and others were used. Therefore, no explicit terminology could be derived for the evaluation work.

The main task of the evaluation was therefore to convert the multidimensional concept of quality of life - which has been developed and applied since the 1960s and 1970s - primarily in the social sciences - into a workable concept that can be used for the evaluation the RDPs. With the help of this theoretically derived research concept, it is possible to illustrate the effects of these programmes on quality of life.

\section{Structure of the article}

This article has two main parts: first a theoretical-conceptual part and then a methodological part. Firstly, we explain the scientific and political importance of quality of life, and of how it developed. We then present approaches for measuring the quality of life that can be applied in assessments of the impact of EAFRD funding. We also examine the political context of the EU, the federal, and the state levels. Within the scope of the impact analysis, the first step is an analysis of the spatial distribution of the funding (incidence analysis) (see Laschewski, 2016). In the second step, we assess the effects of individual EAFRD measures in which improving the quality of life was an explicit goal. Concrete results are presented exemplarily. We then bring together the individual analytical steps, and offer our conclusions.

\section{Scientific and political contexts}

\subsection{Scientific approaches to the measuring of quality of life}

What is quality of life all about, and how can it be measured? Economists and sociologists have investigated and discussed these questions since at least the 1970s. The earlier concept of welfare - which had been measured based on economic developments, as reflected in indicators such as gross domestic product (GDP) and unemployment rates - has gradually disappeared from the general and the scientific terminology. The term "quality of life" was first used by Pigou (Knecht, 2010, p. 16) to distinguish between "non-economic welfare" and "economic welfare."

There is no consensus in the scientific discussion as to what the term "quality of life" means. According to Noll (2000), all efforts to define quality of life have one thing in common, namely, that "quality of life is not the same as standard of living, and cannot be reduced to welfare in the sense of being provided with goods and services" (ibid. p. 7). In this understanding, quality of life is not only determined by the material standard of living but influenced by subjective perceptions and mental states (Goetzke \& Islam, 2017, Gilbert et al., 2016, El-Osta, 2007).

Concepts of quality of life have been developed, particularly in the social sciences, that can connect the different levels of society and that reflect the material and the non-material, the objective and the subjective, and the individual and the collective aspects and components of

5 The federal states of Hamburg, Hesse, Mecklenburg-Western Pomerania, North-Rhine Westphalia, Lower Saxony/Bremen and Schleswig-Holstein decided to commission a joint evaluation of their rural development programmes. The evaluation of EU funding for the entire period of 2007-2013 was performed by the Thünen Institute of Rural Studies, together with its cooperation partners. 
quality of life. These concepts did not, however, become widespread until the 1960s (Knecht, 2010 , p. 17). The most important of these is the multidimensional concept developed by Zapf (1984) that divides objective living conditions and subjective life satisfaction (see Figure 1), a similar structure is elaborated in Gilbert et al. (2016).

\begin{tabular}{|l|l|l|}
\hline \multirow{2}{*}{ Objective life conditions } & \multicolumn{2}{|l|}{ Subjective well-being } \\
\cline { 2 - 3 } & good & bad \\
\hline good & well-being & dissonance \\
\hline bad & adaption & deprivation \\
\hline
\end{tabular}

Fig 1. Welfare positions. Source: Author's own illustration following Zapf, 1984

An investigation of both objective and subjective indicators is necessary to define quality of life. "For empirical research, distinguishing between and comparing objective conditions and subjective well-being as the two components of quality of life has been shown to be very expedient" (ibid., p. 11).

In Germany, the tradition of researching social indicators goes back to the 1950s, providing the foundations for the measurement and analysis of welfare and quality of life. Both objective living conditions and subjective well-being can be measured with the survey tools developed here. The Socio-Economic Panel (SOEP) ${ }^{6}$ is currently the most important survey of living conditions and quality of life for the German population, and provides the relevant indicators and data (on, for example, the living situation, the income, and the financial situation of a household). In assessments of welfare at the societal level, people's perceptions of their own well-being and life satisfaction ${ }^{7}$ are also taken into account. In the SOEP, participants are asked: "All in all, how satisfied are you with your life?" A number of other surveys, such as the European Social Survey (ESS) also use this question.

The objectives of political action "quality of life" and "well-being" are multidimensional concepts with subjective components that must be ascertained and operationalized. The important aspects, dimension and indicators of quality of life have the focus of many studies. In the following, we present approaches for measuring quality of life, and the findings of analyses on quality of life conducted especially in rural areas.

\section{Measuring prosperity and quality of life}

Over the past ten years, the reliance on Gross Domestic Product (GDP) as the indicator of prosperity has been debated at various national and international levels. The critique of GDP includes its failure to adequately take non-market activities, income and social inequality, and other aspects of sustainability into account. For this reason, the focus is increasingly on terms like well-being, which merge objective conditions with life satisfaction.

\section{The Stiglitz-Sen-Fitoussi Commission}

After a number of discussion forums at the Organisation for Economic Co-operation and Development (OECD) and the EU (for an overview, see Kroll, 2011), in 2008, the French government called for the creation of the "Commission on the Measurement of Economic Performance and Social Progress;" or the Stiglitz-Sen-Fitoussi Commission (hereafter, the SSF

\footnotetext{
6 The SOEP is a representative longitudinal survey of private households (panel survey) in Germany that has been conducted annually since 1984 with the same individuals and families. The survey captures objective indicators of the respondents' life situations, as well as subjective indicators of the respondents' life satisfaction. The main instruments of the SOEP are individual and household questionnaires.

${ }^{7}$ For a discussion, see Schupp 2014.
} 
Commission). The SSF Commission included 25 members, five of whom are Nobel laureates. The aim of the commission was to make recommendations for the expansion of the concept of social welfare, and to suggest ways to create suitable indicators for measuring social progress beyond GDP.

The SSF Commission made the case for first measuring the objective conditions that appear to influence quality of life. They decided against, however, identifying individual indicators that reflect quality of life. At the end of 2009 , the commission published a final report, generally referred to as the Stiglitz-Sen-Fitoussi Report (SSF Report, Stiglitz, Sen, und Fitoussi, 2009), in which they formulated dimensions that are intended to reflect the range of factors and components that contribute to quality of life. They also provided criteria to select indicators.

The SFF Commission emphasized the importance of subjective assessments of quality of life (subjective well-being). They observed, for example, that unemployment can have large negative social and psychological effects that go beyond the loss of income; and that the costs of unemployment should therefore not be measured solely in pecuniary terms. Theoretical research approaches on happiness and life satisfaction have suggested that objective conditions have an instrumental character for subjective well-being. According to these approaches, indicators that capture objective conditions can be seen as "proxies," provided that the relationships between objective conditions and subjective assessments are known (see Figure 2).

\begin{tabular}{|c|c|}
\hline Dimensions & Examples of aspects and their distribution \\
\hline Material prosperity & $\begin{array}{l}\text { Income, consumption, changes in wealth; distribution of income } \\
\text { assets }\end{array}$ \\
\hline Health & $\begin{array}{l}\text { Life expectancy, diseases, disabilities, child mortality, physical ar } \\
\text { mental illnesses, health distribution }\end{array}$ \\
\hline $\begin{array}{l}\text { Education (including } \\
\text { vocational training) }\end{array}$ & $\begin{array}{l}\text { Basic reading and writing skills, numeracy skills, ability to solve } \\
\text { problems, information and communication technologies, perform } \\
\text { of school and university students, lifelong learning; distribution of } \\
\text { education }\end{array}$ \\
\hline Personal activities & $\begin{array}{l}\text { Paid employment, commuting, various ways of spending free tim } \\
\text { distribution of personal activities }\end{array}$ \\
\hline $\begin{array}{l}\text { Political influence } \\
\text { and control }\end{array}$ & $\begin{array}{l}\text { Right to vote, legal guarantees, rule of law, opportunities to } \\
\text { participate in the political process, voter turnout, party membersh } \\
\text { rates, unions, non-governmental organizations, participation in } \\
\text { protests, level of democracy, media independence, corruption; } \\
\text { distribution of political influence }\end{array}$ \\
\hline $\begin{array}{l}\text { Social contacts and } \\
\text { relationships }\end{array}$ & $\begin{array}{l}\text { Family ties, friends, intensity of friendships, social contacts, } \\
\text { distribution of social contacts and relationships; distribution of so } \\
\text { contacts and relationships }\end{array}$ \\
\hline $\begin{array}{l}\text { Environmental } \\
\text { conditions }\end{array}$ & $\begin{array}{l}\text { Access to clean air, clean water and uncontaminated land; proxir } \\
\text { to local recreation areas; climate; distribution of environmental } \\
\text { conditions }\end{array}$ \\
\hline $\begin{array}{l}\text { Personal and } \\
\text { economic insecurity }\end{array}$ & $\begin{array}{l}\text { Risks of disease, injury, damage, theft, robbery, murder, death, } \\
\text { unemployment, social marginalization, poverty; distribution of } \\
\text { personal and economic insecurity }\end{array}$ \\
\hline
\end{tabular}

Fig 2. Dimensions and aspects of quality of life according to the SFF Commission. Source: CAE/SVR - Expertise (2010, p. 76) 
The concept of the dimensions of quality of life developed by the SSF Commission has received considerable political attention and has triggered a large number of initiatives and research projects. It also leads to the development of statistical indicator systems. While most scientists have expressed agreement with this concept, there have been some detailed criticisms of this approach. In particular, it was criticised that most of the indicators focus on economics, and that the dimension "housing" is missing (Noll, 2010). The SSF Commission itself points out that the current state of research allows only limited conclusions for policy-making and that a statistical system of long-term surveys of subjective attitudes in many areas still needs to be developed (Stiglitz et al., 2009, p. 44).

At OECD level, the results of the SSF report led to a move away from GDP as the exclusive indicator of social welfare and thus a policy, which correspondingly, was mainly oriented towards economic growth. The OECD pioneered in this newly established field of research, aiming to identify the most meaningful welfare and sustainability indicators, with the goal of creating a more comprehensive picture of social status and social progress. This has significantly improved the conditions for making recommendations for "better policies for better lives" at the international level. Nevertheless, the significance of the "better life index" (OECD, 2011) developed by the OECD is limited, as only a few indicators are available that are comparable across all regions. However, as the index has an easy-to-understand format, the OECD is meeting its goal of introducing and advancing the multidimensional concept of quality of life in political discussions at national, regional, and international levels.

For Germany, social indicator studies - especially the SOEP, the Income and Consumption Survey (Einkommens- und Verbrauchsstichprobe; EVS), and the Household Budget Surveys (Laufende Wirtschaftsrechnungen; LWR) - represent important contributions to ongoing research on quality of life.

\section{Quality of life in rural regions}

Regional analyses of quality of life based on selected indicators are regularly published by various institutions. The Happiness Atlas, which is published annually by the German Post (Raffelhüschen und Schöppner, 2012), compares 13 indicators of quality of life and provides general estimates of life satisfaction at the level of federal states as well as for metropolitan regions of Germany, partly based on the size of the municipality and the settlement structure (2012). Even though the metropolitan regions and the densely populated districts are at the top of the ranking, the differences are small and can, with regard to the major cities, be attributed to the age structure of the big cities (see Raffelhüschen und Schöppner, 2012, p. 151). The northwestern regions and Schleswig-Holstein come out on top in the regional analyses; primarily because these regions were found to have high average levels of family friendliness and high ratings for housing conditions and leisure activities.

The Family Atlas (Knittel \& Lehmann, 2012) focuses on the quality of life of families as a location factor. It maps factors and offers that are relevant for potentially mobile families when deciding whether to move in, move out or stay in a region. The statistics for the districts are analysed. Rural regions often score above average or even well above average in the housing situation.

On the question of housing conditions, a study on quality of life and life satisfaction in rural areas conducted by the Federal Institute for Building, Urban Affairs, and Spatial Research (Bundesinstitut für Bau-, Stadt und Raumforschung) (Sturm und Walther, 2011), came to a similar conclusion. The research found that rural regions offer large advantages in terms of housing quality and space, especially combined with the fact that buying a home is often easier in a rural area. Bauer (2012) supplements the concept of housing quality by describing the attractiveness of residential locations as a central component of quality of life in rural areas. However, rural areas were found to have deficits in the provision of public services. The research also showed that quality of life in rural areas can be problematic for certain groups in particular, such as for older people who live alone and have significant limitations in their ability to perform activities of daily living. Educational and job opportunities were rated as lower in rural communities than in larger cities. 
The importance of social relationships and mutual assistance among neighbours was emphasized in a study by the state government of Saxony-Anhalt (2008, S. 5 f). The study addressed "the degree to which rural families are attracted to living in a local community of a manageable size, and depend on and are involved with their neighbourhoods, local clubs, activities related to civic engagement, small-scale community projects, and town politics." These observations are in line with the findings of research on happiness and satisfaction, which indicate that such "soft factors" can contribute substantially to subjective assessments of quality of life.

The most recent picture of living conditions in rural areas and their development comes from a longitudinal study published in 2015, "Rural Living Conditions in Transition: 1952, 1972, 1993 und 2012" (BMEL, 2015). Comprehensive surveys were also conducted for this research project. The survey results showed that the majority of respondents are generally satisfied with their living conditions, and that in many regions the tendency to leave is compensated by new people moving into the area. However, a number of problem areas were identified in rural villages that cannot be addressed through an expansion of civic engagement, including poor job prospects, a lack of mobility, a lack of cultural and leisure activities for young people, and challenges in combining work and family (ibid., p. 96 f.). As the Family Atlas shows (Knittel \& Lehmann, 2012), the regions that have strengths in these areas rank highly, especially for life satisfaction.

In the discussion above, quality of life is understood as a multidimensional concept, and further measurement developments were presented. This short overview of studies on rural areas points to special priorities with respect to quality of life in rural regions. We have thereby provided a theoretical and conceptual foundation for the methodological research approach used in the evaluation. First, quality of life will be considered within its political context as well as in the country-specific context of EPLR implementation in the funding period 2007 to 2013.

\subsection{Political Context}

\section{Quality of life in EU strategies}

Economic goals are prioritized in the formulation of European strategies.

The goals laid out in the Lisbon Strategy (EU Commission 2005) concentrate on sustainable development.

The goals of the Göteborg Strategy (2001 and 2002) recognized that "economic prosperity," "social justice," and "solidarity" are all dimensions of quality of life. However, they acknowledge that quality of life cannot only be measured by a higher gross national product and positive developments in the labour market.

In the Europe 2020 Strategy, the EU formulated three additional targets: "intelligent growth, sustainable growth, and inclusive growth." With respect to quality of life, the goal of inclusive growth in turn led to the setting of some explicit social targets. The Europe 2020 Strategy emphasizes the social dimensions in Europe, and brings the economic, labour market policy, and social aspects into greater balance. Inclusive growth encompasses the areas of "financial poverty and living conditions," "labour market access," and "education." These aims are measured with target indicators - the so-called Laeken indicators - that have been officially captured and reported by Eurostat, the statistical office of the European Union, since 2008.

The Europe 2020 Strategy also defines attainable, concrete target values for these target indicators. The national target values can, however, differ from the overall aims of the EU. These target indicators and values provide concrete guidance for the assessment of the attainment of quality of life goals in policies for rural areas. These indicators are of central importance, as it is through their application that improvement in the quality of life can be measured. However, their usefulness is limited in Germany because they cannot be fully applied below the NUTS II regional level (in Germany, this level is defined by (some former) government districts and some of the smaller federal states). 


\section{Additional funding instruments and programmes}

"At all levels of government, policy has many opportunities to improve the quality of life of the citizens (Noll, 2015)." Figure 3 shows the policy areas that are important for the goal of improving quality of life.

Thereby, the RDPs fall under the heading of European structural policies. Ahead of the goal of advancing equality in living standards, rural development policies focus on promoting regional development and alleviating disparities in the member states. According to Kaufmann et al. (2007), the stated political rural development goal of "improving the quality of life" refers to the development of rural areas as a place for living, to the differences between rural areas and densely populated areas, and to the various development paths in rural areas.

The most important national financing instrument in Germany is the Joint Task Force for the Improvement of Agricultural Structure and Coastal Protection (GAK), which is jointly financed by federal, state, and national government funding. In addition, the federal states use their own funds as "top-ups."

At the European level, the ERDF and the ESF structural funds are the central instruments of structural and regional policy. These funds also help to ensure that the development goals for rural areas are met. Compared to the national policy areas outlined above, they are less important for issues related to quality of life.

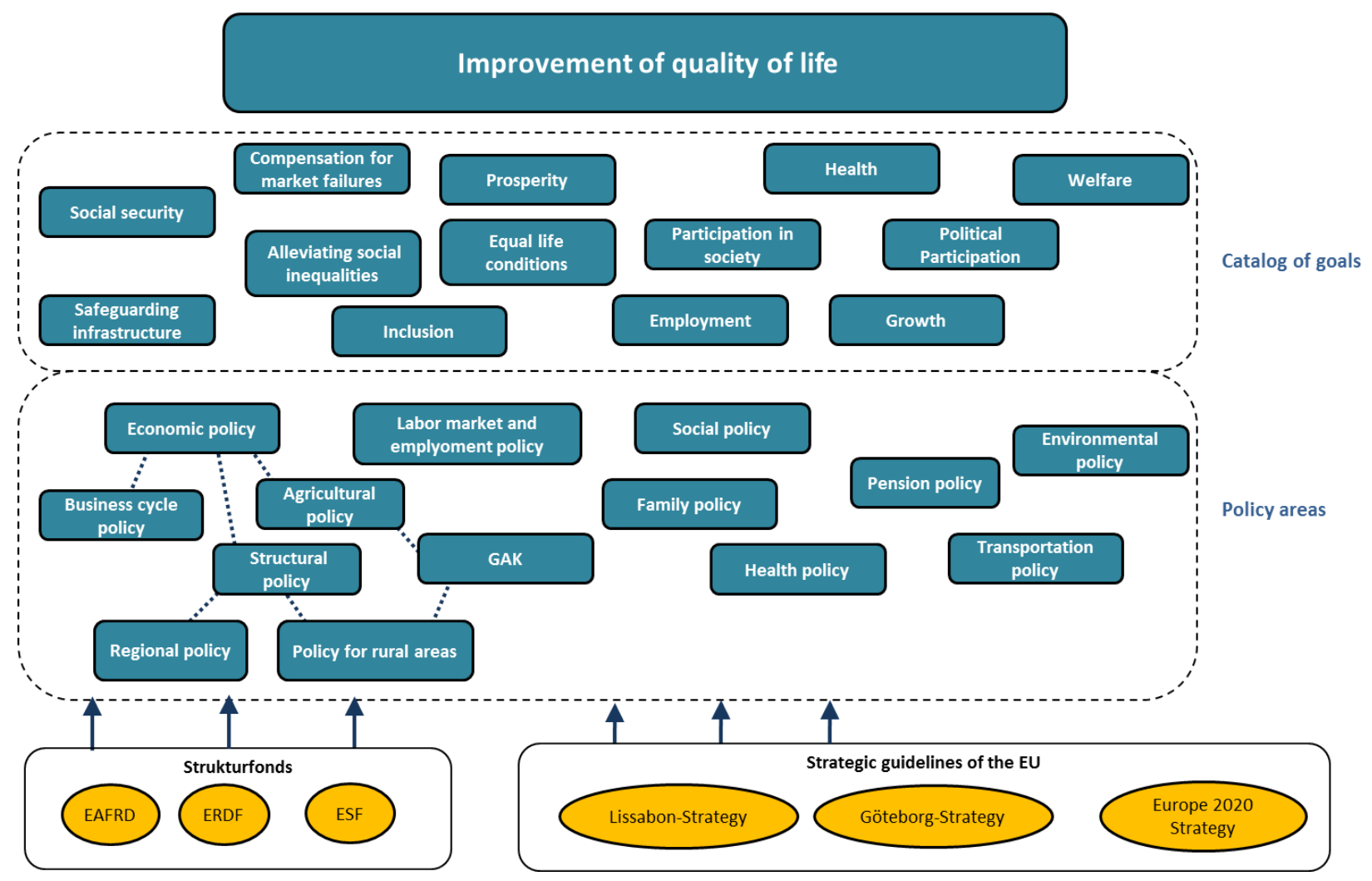

Fig 3. Aims and policy fields affecting quality of life. Source: Author's own illustration 


\section{Quality of life in the strategies of the RDPs studied}

For the 2007-2013 funding period, the EU strategies, the National Strategy of the Federal Republic of Germany, as well as the state-specific sustainability strategies define the scope of the programming of the RPD. The programme strategies center on the four axes of the EAFRD Regulation:

Axis 1 - Improving the competiveness of agriculture and forestry

Axis 2 - Improving the environment

Axis 3 - Improving the quality of life in rural areas and diversifying the rural economy

Axis 4 - LEADER

The analysis of strengths and weaknesses, as well as of opportunities and risks, are the main components of the RDP. The strategic implementation of these programmes depends on the socioeconomic developments and the structural conditions in each country. Different models and strategies were used in the country programmes, and these differences were reflected in their design.

Figure 4 shows the extent to which the financial weighting of these EAFRD Regulation axes varied in the countries studied.

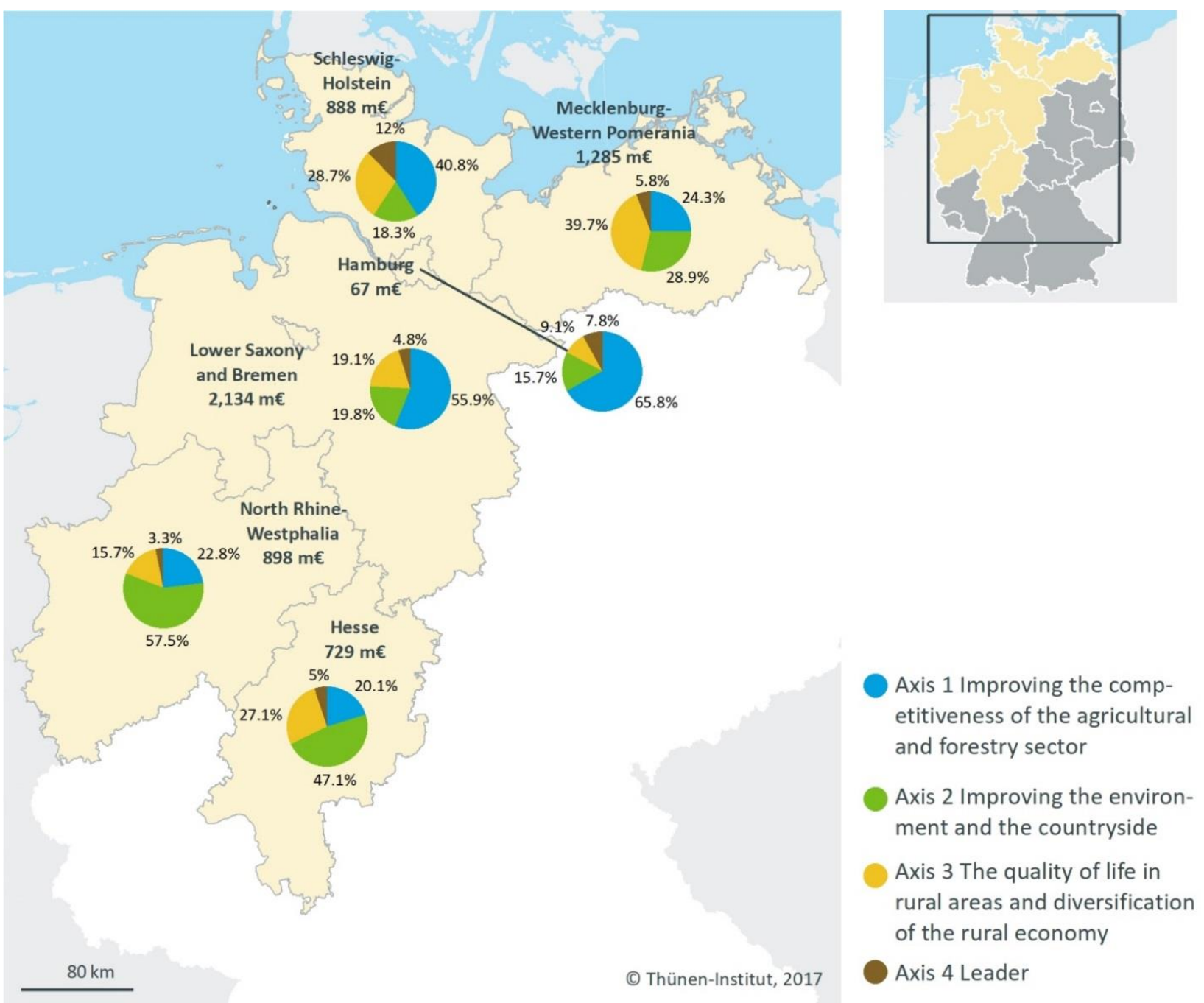

Fig 4. Funds for rural development, public expenditures (EAFRD and national funds, including "top ups"), as of 2012. Source: Author's own illustration following https://www.netzwerk-laendlicher-raum.de/eler/eler-2007-2013/elerin-deutschland/finanzierung/infografik-eler-finanzierung-in-den-laendern/ 
In Lower Saxony and Schleswig-Holstein, goals for agricultural development are especially important. Thus, the axis of the EAFRD Regulation "Improving the competiveness of agriculture and forestry" is a top priority. The EAFRD funding for the improvement of quality of life is integrated in the implementation approach of Axis 3 and LEADER.

For North Rhine-Westphalia and Hesse, improving environmental resources is the primary goal. Thus, for these states, the second axis of the EAFRD "Improving the environment" has the highest priority. In a comparison of the federal states, we can see that in the NRW programme Axes 3 and 4 receive the least financing. This is because given the stable economic development in the rural areas of this state, thus the improvement of these situations is less relevant to the NRW programme.

In Mecklenburg-Western Pomerania, the greatest need is to strengthen the rural labour market and to ensure the availability of basic medical care. Therefore, the axis "Increasing the quality of life in rural areas and diversifying the rural economy," together with LEADER, has the highest priority.

\section{Methodology and Data}

The following research approach allows us to evaluate quality of life in the context of EAFRD funding. The approach is based on the concept of dimensions in the SSF Report (Stiglitz et al., 2009), with appropriate adjustments; and consists of four analytical steps.

In the first step, we provide the theoretical and conceptual background of the approach.

Using a programme analysis based on a document analysis of the RDP, the relevance of the measures aimed at improving the quality of life and of their anticipated effects are analysed. In order to select the relevant measures, the effects of measures are assigned to the various dimensions of quality of life. The detailed results of this step can be found in the ex-post evaluations of each RDP (see Forstner et al., 2016; Moser et al., 2016; Peter et al., 2016; Pollermann et al., 2016; Tietz et al., 2016). An incidence analysis is used to investigate the regional distribution of subsidies, and illustrates the multiple objectives of the funding. Based on the funding in 2007-2012, the financial importance of the subsidies at the district level is examined using the previously selected indicators. The selected funding measures that could at least theoretically have an impact on the dimensions of quality of life are included in the analysis. The goal of the analysis is to investigate the extent to which the spatial distribution of the subsidies compensates for disadvantages in the quality of life dimensions; and whether a goal orientation is reflected therein. In the impact analysis, we combine the results of the evaluation of the measures with the dimensions of quality of life, and assess them in conjunction with the available financial data.

\section{Adaptation of the SSF Concept for the Evaluation}

In order to apply the multidimensional concept of quality of life developed by the SSF Commission (Stiglitz et al., 2009) in the evaluation, we have to adapt the concept to the specific rural living conditions, as well as to the structure and orientation of the EAFRD fund. Thus, the "environment" dimension is represented with the aspects "natural environment," "landscape," and "natural resources." This is because even though having good environmental conditions is an important precondition for having a high quality of life, these conditions play a role in subjective perceptions of quality of life primarily when the population experiences them directly. Measures aimed at protecting resources are deemed as "self-evident." However, in the RDPs studied, "experienced" and directly perceived environmental measures were seldom included in the programme. There were therefore hardly any synergies between these measures and the goals associated with improving the quality of life. For this reason, in the evaluation, the focus on "environment" and living environment was expanded to include the aspects of "natural living environment" and "built environment."

As described above, studies of the quality of life in rural areas highlight the importance of the attractiveness of the living environment and of the quality of living conditions. To capture these aspects, and the corresponding objectives and areas of effectiveness of the subsidies, we 
introduced a new dimension into the analysis: "conditions in residential locations," which is used in other multidimensional concepts of quality of life as well (see Sturm und Walther, 2011, Bauer, 2012). In addition, the dimension "personal activities" differentiates according to whether the activities are related to paid employment or leisure.

The dimensions displayed in Figure 5 are the main evaluation criteria used to measure the quality of life in rural areas.

\begin{tabular}{|c|c|}
\hline Dimensions & Examples of Aspects \\
\hline Material prosperity & Income, consumption, changes in wealth \\
\hline Personal activities (paid employment) & Paid work, commuting \\
\hline Personal activities (leisure, etc.) & Types of leisure activities \\
\hline Personal and economic insecurity & $\begin{array}{l}\text { Employment opportunities, Unemployment, } \\
\text { economic development, risk of illness, social } \\
\text { marginalization, poverty, crime ... }\end{array}$ \\
\hline Health & Life expectancy, diseases, disabilities \\
\hline $\begin{array}{l}\text { Education (including vocational } \\
\text { training) }\end{array}$ & $\begin{array}{l}\text { Performance of school and university students, } \\
\text { lifelong learning ... }\end{array}$ \\
\hline Social relationships & $\begin{array}{l}\text { Club membership, family ties, friends, social } \\
\text { activities (festivities) and contacts }\end{array}$ \\
\hline Political participation & $\begin{array}{l}\text { Participation, civic engagement, opportunities to } \\
\text { take part in the political process, non-governmental } \\
\text { organizations }\end{array}$ \\
\hline Conditions of residential location & $\begin{array}{l}\text { Condition of buildings and streets, infrastructure, } \\
\text { population development ... }\end{array}$ \\
\hline Environmental conditions & $\begin{array}{l}\text { Natural environment, landscape, natural } \\
\text { surroundings in residential areas, built environment } \\
\ldots\end{array}$ \\
\hline
\end{tabular}

Fig 5. Ten dimensions of quality of life in rural areas. Source: Author's own compilation based on the SSF Report (Stiglitz et al., 2009)

\section{Spatial distribution of EAFRD funding (incidence analysis)}

In order to examine to what extent the funding from the RDP is focused on the spatial differences in living conditions in rural regions, we present an analysis of the spatial distribution of the subsidies. In conducting this analysis, we used an incidence analysis at the district level (see Laschewski, 2013 \& 2016), as both information on the subsidy payments made by the RDPs and sufficient statistical data on quality of life are available at this level, and can be evaluated. We included in the analysis the measures that were identified in the relevance analysis as having at least a theoretical effect on the dimensions of quality of life. The analysis was based on the examples of leading indicators and the composite indicators of the dimensions formulated in the SFF Report ${ }^{8}$.

\footnotetext{
${ }^{8}$ This approach is based on a common opinion formulated by a panel of experts tasked with evaluating macroeconomic development and the French Conseil d'Analyse Économique (CAE/SVR, 2010).
} 
Table 1 provides an overview of the indicators that were ultimately included in the incidence analysis. For the area of "personal activities and unemployment", the leading indicator was the unemployment rate. For other questions - for example, questions about financial risk or health care - several indicators were summarized into a single indicator ${ }^{9}$. Economic aspects were assigned to a dimension that includes the factors such as GDP per capita, household income, and employee compensation. We then applied a factor analysis, a statistical procedure for reducing complexity. The advantage of using such a statistical algorithm is that it allows for greater objectivity in the selection of leading indicators. However, the use of this procedure can create problems, such as concerns about whether the content is appropriate, and about the interpretability of the resulting indicators. The dimensions "health" and "personal and economic security" were also aggregated into a single factor made up of several different indicators, including the ratio of residents to physicians and the number of paediatricians per 100,000 children.

The analysis of the regional distribution is based on the hypothesis that the regional distribution of the subsidies is influenced less by performance indicators related to quality of life than by the regional importance of agriculture, as the EAFRD is considered the second pillar of the Common Agricultural Policy. Therefore, the distribution was tested using the control variables of the share of workers employed in agriculture and the share of agricultural land.

Tab 1. Dimensions of quality of life and key indicators included in the incidence analysis. Source: Author's own compilation following Laschewski $(2013$ \& 2016)

\begin{tabular}{|l|l|}
\hline Personal activities/employment & Key indicators \\
\hline Personal security & Unemployment (2006) \\
\hline Economic security & $\begin{array}{l}\text { Factor FinRisk <-(consumer insolvencies, debt ratio, } \\
\text { employment) }\end{array}$ \\
\hline Migration & Migration balance (2006) \\
\hline Regional importance of agriculture & Share of workers employed in agriculture \\
\hline Land use & Share of land used for agricultural purposes (2010) \\
\hline
\end{tabular}

The incidence analysis reveals the extent of the contributions made by the RDPs. The findings indicate that in the RDPs studied, the indicators of quality of life are correlated with the subsidies provided for the relevant measures to a limited extent only. It is therefore clear that the subsidy payments were only slightly oriented toward the dimensions of quality of life. In some cases, a positive relationship between a problem area and a deployment of funds occurred accidentally; while in other cases, the distribution of financial resources was in conflict with the distribution of problem areas. No effects could be shown. For example, for Lower Saxony, it was apparent that the distribution of subsidies corresponded to the regional importance of the agricultural sector, even though the analysis took into account only the measures that were relevant for quality of life. Funding for investments in agriculture were, for example, not included.

Similarly, in Mecklenburg-Western Pomerania, the quantitative analysis of the regional distribution of subsidies showed that the funding primarily reflected the share of employment in the primary sector and the amount of agricultural land, and did not correspond to quality of life indicators. The analysis further showed that the actual distribution of subsidies with respect to quality of life were non-specific, or even went in a negative direction. This means that more funding went to the districts in which income and employment levels, as well as the state of the rural infrastructure, were relatively positive.

\footnotetext{
${ }^{9}$ The "unemployment rate" indicator can be found in two dimensions: "Personal activities/employment" and "Personal security". This is possible because the individual dimensions results are not aggregated or correlated but rather viewed individually.
} 
In Hesse alone a clear positive correlation was found between the amount and regional distribution of per person RDF funding and indicators of quality of life in problem areas. Figure 6 displays the example of the interrelation between the regional distribution of subsidies and the factor of financial risk. The trend line rises, which indicates that the distribution of the subsidies depends on economic indicators related to quality of life. However, the results also show that the relationship is determined above all by the dimension "Rusticity" (population density), and that the funding was oriented toward this aspect in particular. Moreover, this "good" fit could be attributable to the small number of cases in Hesse, whereby a single outlier could have a relatively large influence on the trend line. Thus, the results of this analysis provide an initial point of reference, but are not sufficient to allow for a final assessment.

The incidence analyses we conducted are based solely on statistical data on objective living conditions. The analyses offer initial points of reference, but they do not allow us to make a final assessment, as subjective assessments are not taken into account.

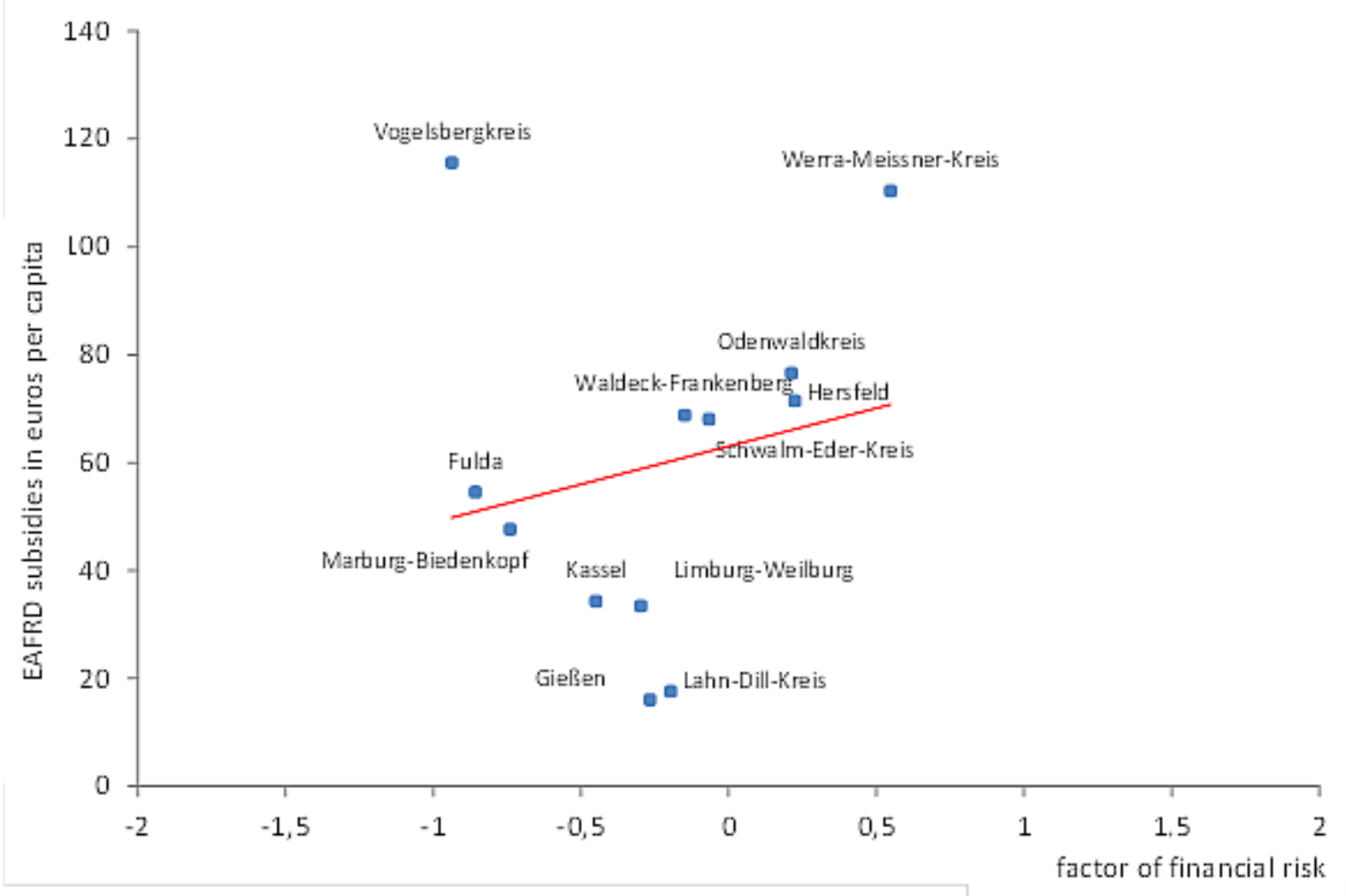

Fig 6. Association between the regional distribution of subsidies and a composite factor of financial risk, based on the example of the RDP in Hesse. Source: Author's own calculations.

\section{Effects of the relevant measures on the dimensions of quality of life based on the example of Mecklenburg-Western Pomerania}

The results of the impact analysis of the RDP are demonstrated using the example of the RDP in Mecklenburg-Western Pomerania. As we showed above, the evaluation is based on the relevant measures found in the programme analysis: i.e., the key measures that affect the quality of life in rural areas (see Moser, 2016).

The selection of relevant measures was based on the following two criteria:

For the measure, explicit goals are formulated with regard to quality of life in the programme.

For the measure, the programme includes no explicit goals related to quality of life; but indirect positive effects on dimensions of quality of life may theoretically be expected. 
Tab 2. Allocation of subsidies to the dimensions of quality of life in the example of the RDP in Mecklenburg-Western Pomerania. Source: Author's own illustration.

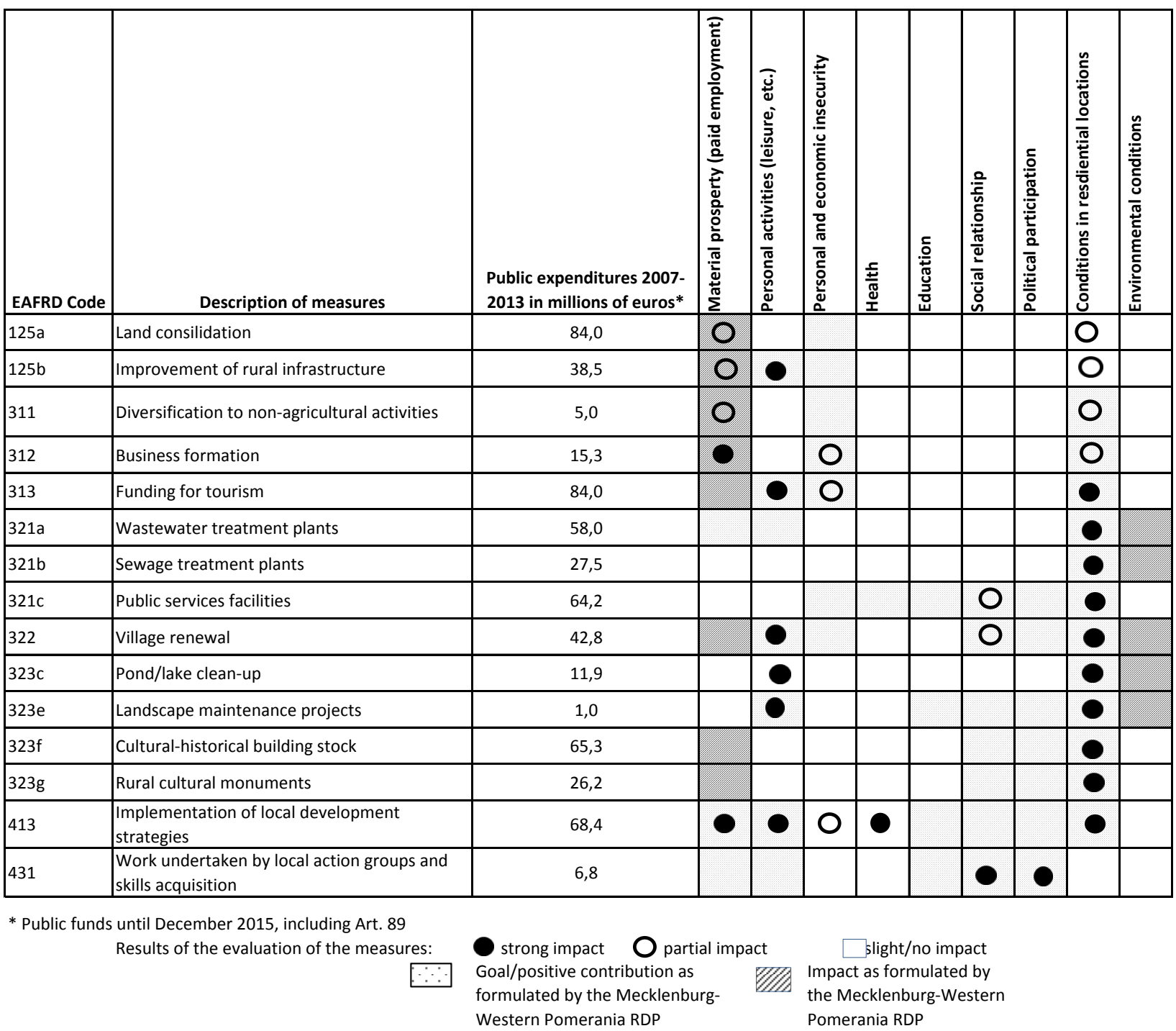

The EAFRD measures in Axis 3, "Improving the quality of life in rural areas and diversifying the rural economy," can be most clearly identified as structural policies, and therefore have considerable potential to affect improvements in the quality of life. In this axis, measures such as improving public services and establishing service providers dedicated to village renewal and the conservation of rural heritage are implemented in conjunction with measures aimed at diversifying the rural economy, promoting business formation and development, and promoting tourism. Within the scope provided by the EAFRD Regulation, Mecklenburg-Western Pomerania was able to take full possibilities of Axis 3 .

Table 2 provides an overview of the measures and dimensions of quality of life for MecklenburgWestern Pomerania, and displays the objectives of the RDP from the programme analysis in relation to the performance assessments in the evaluation of the measures.

It thus becomes clear that the intensity of the impact of the respective measures in each of the dimensions was very different. However, the allocation of the contributions of the measures that was found in the programme analysis did not correspond in all areas with that of the evaluation of the measures. Of the relevant EAFRD measures, the axis of the dimension "conditions in residential locations" appears to be particularly salient. The evaluation of the measures is particularly important: all of the measures were found to have an effect on this dimension, except for Measure 431, "work of local action groups." 


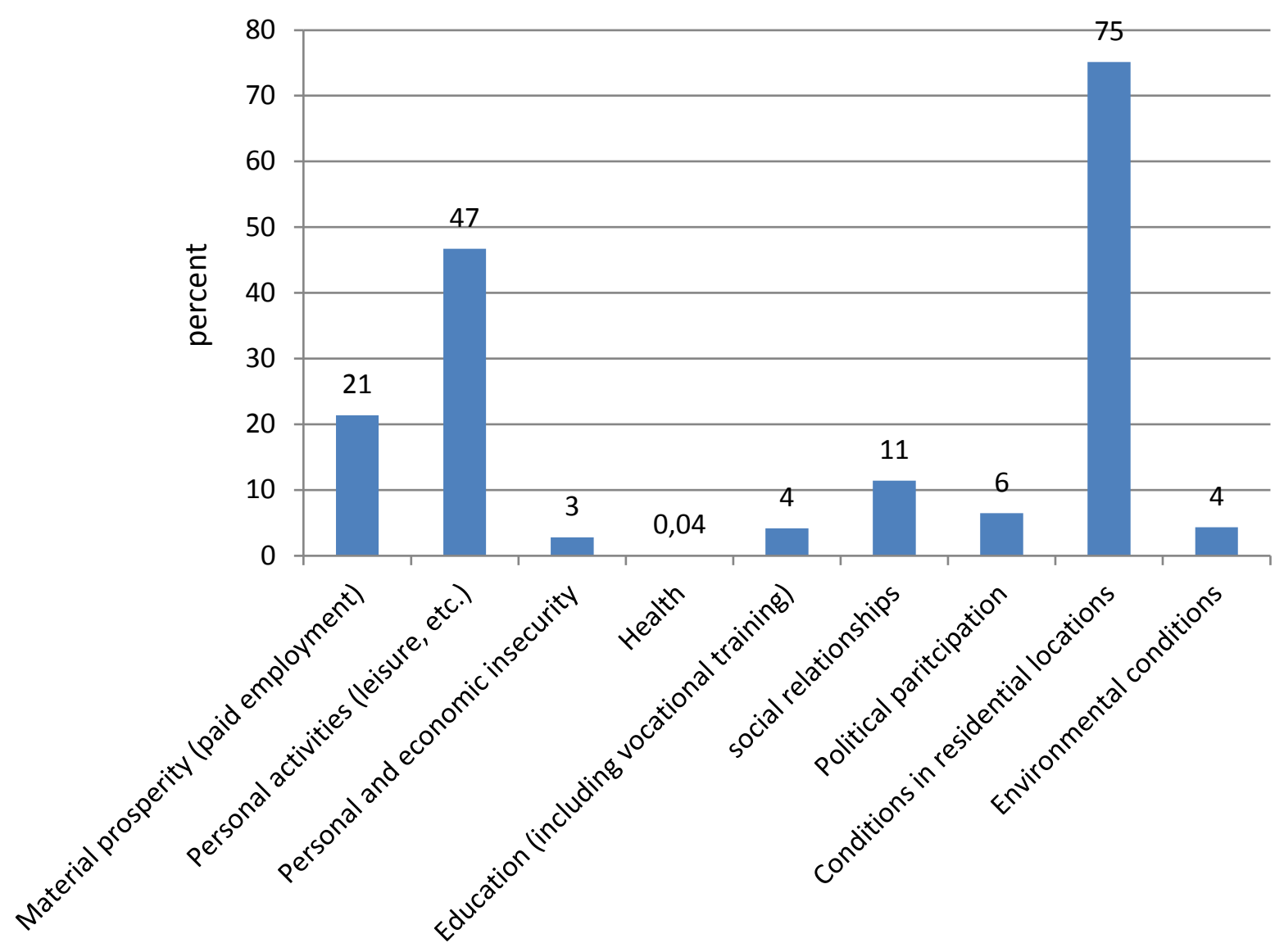

Fig 7. Percent shares of the subsidies granted in 2007-2014 for the dimensions of quality of life in the example of the Mecklenburg-Western Pomerania RDP. Source: Author's own illustration.

Figure 7 illustrates this axis. It shows the shares of the subsidies from 2007 to $2014^{10}$ that were aggregated to the dimensions. The subsidies were allocated to multiple dimensions, or were only partially allocated to these dimensions ${ }^{11}$ (see Table 2).

The SSF Commission provides no recommendations for "ranking" the dimensions in terms of their importance in the canon of quality of life. The bulk of the funding measures of the MecklenburgWestern Pomerania RDP were allocated to the key measures identified as the most relevant for quality of life, with the greatest emphasis placed on the dimension "conditions in residential locations." The greatest share of the subsidies - 75\% - was applied to this dimension (see Figure 7).

The key measure for the dimension "conditions in residential locations" was village renewal and development (322), together with Measure 413 for the improvement of quality of life in the LEADER regions. The measures relevant for the conservation and improvement of quality of life contributed to the dimension "personal activities (leisure)." The dimension "material prosperity" achieved a share of $21 \%$, primarily due to schemes related to diversification (311) and business formation (312). Few or no subsidies were allocated to the dimensions "education" and "health."

The main impact of the Axis 3 measures, and especially village renewal and development (322), was in the area of "conditions in residential locations," with measures aimed at designing buildings and traffic areas in order to conserve and improve the image of the village, thereby making it more attractive to residents and visitors. Conversion projects could be conducted to preserve rural

10 Due to the $n+2$ rule, payments under the funding period 2007 to 2013 are still possible until the end of 2015 . At the time the report was drawn, funding data was available until the end of 2014 .

11 In the evaluation of the measures, paid subsidies were allocated to the dimensions of quality of life based on their strong $(100 \%)$ or their partial $(30 \%)$ effects. 
building stock. The strategic orientation of measures aimed at improving public services, such as projects supporting technical infrastructure and infrastructure facilities, was a second central aspect of the dimension of "conditions in residential locations." In this context, basic services such as wastewater and sewage treatment plants (321), village renewal and development (322), and LEADER made large contributions to increasing the attractiveness of rural areas as places for living and working. These services were enhanced with improvements in the technical infrastructure and the establishment and preservation of institutions focused on meeting the social and medical needs of the residents (e.g., village community centres, kindergartens, facilities for shopping and for fulfilling everyday needs).

Projects designed to improve the tourism infrastructure (313) were focused primarily on improving land use and local recreational areas to promote active holidays for the population; as well as on conserving and enhancing rural and cultural heritage (323). Through LEADER, a wide range of projects was implemented with active participation (Pollermann et al. 2013). In addition, the projects contributed to several dimensions, including "conditions in residential locations." Ideas for projects tailored to regional conditions were developed through the mobilization and bringing together of relevant local actors, and through inter-municipal and cross-sectoral cooperation. The establishment of new businesses (312) led to more employment. The LEADER projects were also linked to employment effects.

Projects implemented in the area of land consolidation and road construction (125) were aimed at improving the infrastructure. The combination of village renewal and land consolidation initiatives heightened the overall impact of these projects, and had lasting effects on rural development in the communities. Moreover, multifunctional connecting roads that also served as routes for bicycles contributed to the dimensions "personal activities (leisure)" and "conditions in residential locations;" and thus to mobility, leisure and recreational activities, and quality of life.

\section{Conclusions}

For the 2007-2013 funding period, the aims of the EU Commission included improving the quality of life in rural areas through funding provided by the EAFRD. To date, however, the EU Commission has no comprehensive concept for this programme. A multidimensional concept was developed within the framework of the seven-country evaluation. The results show that efforts by the RDP to improve the quality of life have been only partially successful. Across all countries, the mix of RDP measures that scored especially high were those in the dimensions "conditions in residential locations" and "personal activities (leisure, etc.)." The quantitative analysis (incidence analysis) focused on objective living conditions, and thus provided an initial reference point for evaluating the regional distribution of the funding. However, the results are not sufficient to allow us to make a final assessment. Future research should investigate the effects of the funding at the district level by analysing selected indicators.

With this multidimensional concept, the goal of "improving the quality of life" was more fully elaborated for the purposes of policy-making. In the process, however, it became clear that objectively evaluating the effects of policies on the quality of life in rural areas is difficult. First, the structure of the RDPs and their measures differ considerably, and indicators that would allow for the quantification of their effects were missing. We therefore recommend that the federal states discuss the question of what constitutes "the good life" in rural areas. Future research should also investigate the subjective assessments, and measure life satisfaction as an indicator using surveys. In the area of public services and infrastructure, we recommend strengthening and expanding the range of measures focused on the design of and support for services and communal facilities.

Beyond the look at the RDPs in general, the national policies have the greatest influence on efforts to improve quality of life at the federal, state, and district levels. The main policy areas are economic and labour market policies, as well as social policies. Compared with the instruments and opportunities for action and the level of funding these policy areas have at their disposal, the RDP is of little importance. However, by focusing on issues like employment and public services, Mecklenburg-Western Pomerania in particular can start to close the gap in tackling the special challenges associated with rural development. 
[1] Bauer, J. (2012). Strategien und Maßnahmen zur Entwicklung von Lebensqualität und Attraktivität in einer ländlichen Gemeinde unter besonderer Berücksichtigung der Erwachsenen im Alter von 18-50 Jahren - am Beispiel des Marktes Heiligenstadt i. OFr. [working paper]. Kaiserslautern: Technische Universität.

[2] Copus, A., Shucksmith, M., Dax, T. \& Meredith, D. (2011). Cohesion Policy for rural areas after 2013. Studies in Agricultural Economics 113, 121-132.

[3] El-Osta, H. S. (2007). The determinants of a quality of life indicator for farm operator households: application of zero-inflated count-data models. Applied Research in Quality of Life 2(3), 145-163. DOI: 10.1007/s11482-007-9035-1.

[4] Forstner, B., Grajewski, G., Bathke, M., Bergschmidt, A., Dickel, R., Eberhardt, W., Ebers, H., Fährmann, B., Fengler, B., Franz, K., Moser, A, Pufahl, A., Reiter, K., Roggendorf, W., Sander, A., Schnaut, G., Schwarz, G., Spengler, M. \& Tietz, A. (2016). Ex-post-Bewertung Entwicklungsplan für den ländlichen Raum des Landes Hessen 2007 bis 2013 [research report]. Braunschweig: Thünen Institut.

[5] Gilbert, A., Colley, K. \& Roberts, D. (2016). Are rural residents happier? A quantitative analysis of subjective wellbeing in Scotland. Journal of Rural Studies, 44, 37-45. DOI: 10.1016/j.jrurstud.2016.01.002.

[6] Goetzke, F. \& Islam, S. (2017). Testing for Spatial Equilibrium Using Happiness Data. Journal of Regional Science, 57(2), 199-217. DOI: 10.1111/jors.12311.

[7] Grieve, J. \& Weinspach, U., eds. (2010). Capturing impacts of LEADER and of measures to improve Quality of Life in Rural areas. The Hague: European Association of Agricultural Economists.

[8] Kaufmann, P., Stagl, S., Zawalinska, K. \& Michalek, J. (2007). Measuring Quality of Life in Rural Europe - a Review of Conceptual Foundations. Eastern European Countryside, 13, $1-21$.

[9] Knecht, A. (2010). Lebensqualität produzieren. Ressourcentheorie und Machtanalyse des Wohlfahrts-staats. Wiesbaden: VS Verlag für Sozialwissenschaften.

[10] Knittel, T. \& Lehmann, C. (2012). Familienatlas 2012. Berlin: Bundesministerium für Familien, Senioren, Frauen und Jugend.

[11] Kroll, C. (2011). Wie wollen wir zukünftig leben? Internationale Erfahrungen bei der Neuvermessung von Fortschritt und Wohlergehen [working paper]. Berlin: Rat für Sozial und Wirtschaftsdaten.

[12] Laschewski, L. (2016). Regionale Indikatoren Guten Lebens - Eine methodische Skizze für die Erstellung von Indikatorensets zur Erfassung von Dimensionen der Lebensqualität auf Kreisebene. In Häfner, D., Laschewski, L. \& Zieschank, R., eds., Regionale Indikatoren Gutes Leben (pp. 23-50). Cottbus, Brandenburgische technische Universität.

[13] Moser, A. (2016). Ex-post-Bewertung EPLR M-V 2007-2013: Modulbericht 9.9_MB Lebensqualität [research report]. Braunschweig: Thünen-Institut.

[14] Moser, A., Grajewski, R., Bathke, M., Bergschmidt, A., Dickel, R., Eberhardt, W., Ebers, H., Fähr-mann, B., Fengler, B., Forstner, B., Franz, K., Peter, H., Pufahl, A., Reiter, K., Roggendorf, W., Sander, A., Schnaut, G., Schwarz, G., Spengler, M. \& Tietz, A. (2016). Expost-Bewertung NRW-Programm Ländlicher Raum 2007 bis 2013 [research report]. Braunschweig: Thünen Institut.

[15] Noll, H.-H. (2000). Konzepte der Wohlfahrtsentwicklung: Lebensqualität und "neue" Wohlfahrtskonzepte [working paper]. Wissenschaftszentrum Berlin für Sozialforschung. 
[16] Noll, H.-H. (2010). The Stiglitz-Sen-Fitoussi-Report: Old Wine in New Skins? Views from a Social Indicators Perspective. Social Indicators Research 102(1), 111-116. DOI: 10.1007/s11205-010-9738-9.

[17] Peter, H., Grajewski, R., Bathke, M., Bergschmidt, A., Dickel, R., Eberhardt, W., Ebers, H., Fährmann, B., Fengler, B., Forstner, B., Franz, K., Moser, A., Pollermann, K., Pufahl, A., Reiter, K., Roggendorf, W., Sander, A., Schnaut, G., Schwarz, G. \& Spengler, M. (2016). Expost-Bewertung Entwicklungsprogramm für den ländlichen Raum MecklenburgVorpommern 2007 bis 2013 [research report]. Braunschweig: Thünen-Institut.

[18] Pollermann, K., Grajewski, R., Bathke, M., Bergschmidt, A., Dickel, R., Eberhardt, W., Ebers, H., Fährmann, B., Fengler, B., Forstner, B., Franz, K., Moser, A., Pufahl, A., Reiter, K., Roggendorf, W., Sander, A., Schnaut, G., Schwarz, G., Spengler, M. \& Tietz, A. (2016). Expost-Bewertung. Entwicklungsprogramm für den ländlichen Raum des Landes SchleswigHolstein 2007 bis 2013 [research report]. Braunschweig: Thünen Institut.

[19] Pollermann, K., Raue, P. \& Schnaut, G. (2013). Rural Development experiences in Germany: opportunities and obstacles in fostering smart places through LEADER. Studies in Agricultural Economics 115(2), 111-117.

[20] Schupp, J. (2014). 40 Jahre Sozialberichterstattung und Lebensqualitätsforschung in Deutschland - Rückblick und Perspektiven. SOEPpapers 680, 1-18.

[21] Stiglitz, J.-E., Sen, A. \& Fitoussi, J.-P. (2009). Report by the commission on the measurement of economic performance and social progress [research report]. Paris: Commission on the measurement of economic performance and social progress.

[22] Sturm, G. \& Walther, A. (2011). Lebensqualität in kleinen Städten und Landgemeinden [research report]. Bonn: Bundesamt für Bauwesen und Raum-ordnung.

[23] Tietz, A., Grajewski, R., Bathke, M., Bergschmidt, A., Dickel, R., Eberhardt, W., Ebers, H., Fähr-mann, B., Fengler, B., Forstner, B., Franz, K., Peter, H., Pufahl, A., Reiter, K., Roggendorf, W., San-der, A., Schwarz, G., Spengler, M., Moser, A. \& Pollermann, K. (2016). Ex-post-Bewertung PRO-FIL 2007 bis 2013 - Programm zur Förderung im ländlichen Raum Niedersachsen und Bremen [research report]. Braunschweig: Thünen Institut.

[24] Zapf, W. (1984). Individuelle Wohlfahrt: Lebensbedingungen und wahrgenommene Lebensqualität. In: Glatzer, W., Zapf, W., eds., Lebensqualität in der Bundesrepublik Deutschland (pp. 13-27). Frankfurt am Main: Campus Verlag.

Other sources

[25] BMEL, Bundesministerium für Ernährung und Landwirtschaft (Hg.) (2015). Ländliche Lebensverhältnisse im Wandel 1952, 1972, 1993 und 2012. Berlin.

[26] CAE (Conseil d'Analyse Économique)/SVR (Sachverständigenrat) - Expertise (2010). Sachverständigenrat zur Begutachtung der gesamtwirtschaftlichen Entwicklung und Conseil d'analyse écono-mique: Wirtschaftsleistung, Lebensqualität und Nachhaltigkeit: Ein umfassendes Indikatorensystem. Wiesbaden / Paris.

[27] EEN, European Evaluation Network for Rural Development (2014). Capturing the success of your RDP: Guidelines for the Ex Post Evaluation of 2007-2013 RDPs. European Evaluation Network for Rural Development. Brüssel.

[28] ELER-Verordnung. VO (EG) Nr. 1698/2005: Verordnung (EG) Nr. 1698/2005 des Rates vom 20. September 2005 über die Förderung der Entwicklung des ländlichen Raums durch den Europäischen Landwirtschafts-fonds für die Entwicklung des ländlichen Raums (ELER). Brüssel.

[29] EU-KOM, Kommission der Europäischen Gemeinschaften (2005). Mitteilung der Kommission an den Rat und das Europäische Parlament. Gemeinsame Maßnahmen für 
Wachstum und Beschäftigung: Das Lissabon-Programm der Gemeinschaft. Europäische Kommission. Brüssel.

[30] Eurostat (2015). Quality of life. Facts and views. Publications Office of the European Union, Luxembourg.

[31] Frey, B. S. (2012). Glück in der Gesellschaft. In Deutsche Post Glücksatlas. München.

[32] Landesregierung Sachsen-Anhalt (2008). Wege zu einer nachhaltigen Bevölkerungspolitik in Sachsen-Anhalt. Ländliche Lebensmodelle junger Menschen und Familien - Kurzfassung zum Abschlussbericht. Magdeburg.

[33] Laschewski, L. (2013). Lebensqualität in der ELER-Förderung in fünf Bundesländern Literaturbericht und Analyse regionalisierter Förderdaten. 03.11.2013 (unpublished).

[34] Noll, H.-H. (2015). Arbeitslosigkeit, Armut und soziale Isolierung beeinträchtigen Lebensqualität. Beitrag im Blog der Bundesregierung vom 07.05.2015. https://buergerdialog.gut-leben-in-deutschland.de/SharedDocs/Blog/DE/2015-05-07gastbeitrag-heinz-herbert-noll.html. zitiert am 24.05.2016.

[35] OECD, Organisation for Economic Co-operation and Development (2011). How's Life? Measuring well-being. OECD Publishing.

[36] Raffelhüschen, B., Schöppner, K.-P. (2012). Deutsche Post Glücksatlas. Bonn. 